\title{
ISLET TRANSPLANTATION IN RODENTS. Do encapsulated islets really work?
}

\author{
Yngrid Ellyn Dias Maciel de SOUZA', Eleazar CHAIB², Patricia Graça de LACERDA ${ }^{1}$, \\ Alessandra CRESCENZI ${ }^{3}$, Arnaldo BERNAL-FILHO ${ }^{3}$ and Luiz Augusto Carneiro D'ALBUQUERQUE ${ }^{2}$
}

\begin{abstract}
Context - Diabetes mellitus type I affects around 240 million people in the world and only in the USA $7.8 \%$ of the population. It has been estimated that the costs of its complications account for $5 \%$ to $10 \%$ of the total healthcare spending around the world. According to World Health Organization, 300 million people are expected to develop diabetes mellitus by the year 2025. The pancreatic islet transplantation is expected to be less invasive than a pancreas transplant, which is currently the most commonly used approach. Objectives - To compare the encapsulated and free islet transplantation in rodents looking at sites of islet implantation, number of injected islets, viability and immunosuppression. Methods - A literature search was conducted using MEDLINE/PUBMED and SCIELO with terms about islet transplantation in the rodent from 2000 to 2010. We found 2,636 articles but only 56 articles from 2000 to 2010 were selected. Results - In these 56 articles used, 34\% were encapsulated and 66\% were nonencapsulated islets. Analyzing both types of islets transplantation, the majority of the encapsulated islets were implanted into the peritoneal cavity and the nonencapsulated islets into the liver, through the portal vein. In addition, the great advantage of the peritoneal cavity as the site of islet transplantation is its blood supply. Both vascular endothelial cells and vascular endothelial growth factor were used to stimulate angiogenesis of the islet grafts, increasing the vascularization rapidly after implantation. It also has been proven that there is influence of the capsules, since the larger the capsule more chances there are of central necrosis. In some articles, the use of immunosuppression demonstrated to increase the life expectancy of the graft. Conclusion - While significant progress has been made in the islets transplantation field, many obstacles remain to be overcome. Microencapsulation provides a means to transplant islets without immunosuppressive agents and may enable the performance of xenotransplantation. The use of alternative donor sources, fewer islets per capsule and the appropriate deployment location, such as the peritoneal cavity, may give a future perspective to the application of immunoprotective capsules and viability in clinical practice. A variety of strategies, such as genetic engineering, co-encapsulation, improvement in oxygen supply or the establishment of hypoxia resistance will also improve the islet transplantation performance. It remains to be determined which combination of strategies with encapsulation can fulfill the promise of establishing a simple and safe transplantation as a cure for diabetes.
\end{abstract}

HEADINGS - Diabetes mellitus, type I. Islets of Langerhans transplantation. Rodentia.

\section{INTRODUCTION}

Diabetes mellitus (DM) type I affects around 240 million people in the world ${ }^{(1)}$ and only in the USA $7.8 \%$ of the population ${ }^{(55)}$. It has been estimated that the costs of its complications account for $5 \%$ to $10 \%{ }^{(20)}$ of the total healthcare spending around the world. According to World Health Organization, 300 million people are expected to develop DM by the year 2025 .

Islet transplantation has been considered a safer alternative than whole-organ transplantation and a potentially alternative treatment to conventional exogenous-insulin therapy ${ }^{(16)}$. The main benefit of islet transplantation is the ability to inject it in vascularized organs and it can be considered less invasive. The acute rejection still is a major problem. New alternatives to avoid the rejection have been developed such as, thymic manipulation, co-transplant with other cell types (bone marrow cells, Sertoli cells etc.), liver transplantation ${ }^{(27,}$ $37,41,42)$ and encapsulated islets.

With immunoprotection by encapsulation, islets are enclosed in a matrix surrounded by semipermeable membrane, which allows for the passage of small molecules like insulin and glucose, but not for the entry of the much larger cells and antibodies of the immune system. Such a physical barrier can thus prevent allograft rejection, which depends on recognition of the Major Histocompatibility Complex (MHC) by host lymphocytes. Furthermore it can prevent antibody-mediated cytotoxicity, which plays a role in the autoimmune destruction of beta cells, as well as in allograft and xenograft rejection ${ }^{(31,59)}$. Immunoprotection by encapsulation can thus enable transplantation of islet tissue in the absence of immunossupression.

Our aim is to compare the encapsulated and free islet transplantation in rodents looking at site of

Universidade Nove de Julho, São Paulo, SP; ${ }^{2}$ Faculdade de Medicina da Universidade de São Paulo, USP, ${ }^{3}$ Curso de Pós-graduação, Faculdade de Medicina da Universidade de São Paulo, São Paulo, SP, Brasil.

Correspondence: Prof. Eleazar Chaib - Department of Gastroenterology - University of Sao Paulo School of Medicine - Av. Dr Arnaldo, 455 - $3^{\circ}$ andar - $01246-903$, São Paulo, SP, Brazil. E-mail: eleazarchaib@yahoo.co.uk 
implantation, number of islets, viability and type of immunosuppression.

\section{METHODS}

This research was made through MEDLINE/PUBMED and SCIELO web sites looking for papers on the content "islet transplantation in the rodent".

We found 2,636 articles but only 56 articles from 2000 to 2010 were selected based on the relevance. Thirty-five $(35 \%)$ were about encapsulated islet and sixty-five $(65 \%)$ nonencapsulated islet. There were articles about xenografts, isografts and allografts.

\section{RESULTS}

The best islet survival rate in encapsulated islet transplantation was achieved in the peritoneal cavity with an average of 4216 islets implanted per capsule, lasting an average of 100 days functionally (Table 1).

TABLE 1 . Sites of implantation of encapsulated islets and islets survival rate (days)

\begin{tabular}{lcc}
\hline \multicolumn{3}{c}{ Encapsulated } \\
\hline Author & $\begin{array}{c}\text { No. of islets per } \\
\text { capsule }\end{array}$ & Results days \\
\hline & Peritoneal cavity \\
\hline Tatarkiewicz et al. ${ }^{(53)}$ & 2000 & 70 \\
Omer et al. ${ }^{(35)}$ & 3000 & $21-70$ \\
Figliuzzi et al. ${ }^{(11)}$ & 16000 & IS $+: 18 \pm 8$ \\
Yun Lee et al. ${ }^{(63)}$ & 1200 & IS-: $7.5 \pm 0.2$ \\
Remuzzi A et al. ${ }^{(39)}$ & 3000 & $>365$ \\
O'Sullivan et al. ${ }^{(36)}$ & 100 & 80 \\
\hline \multicolumn{3}{c}{ Subcutaneous tissue } \\
\hline Sorenby et al. ${ }^{(48)}$ & 200 to 1000 & 14 \\
Sorenby et al. ${ }^{(49)}$ & 125 to 375 & 28 \\
\hline \multicolumn{3}{c}{ Liver } \\
\hline Schneider S. et al. ${ }^{(44)}$ & 1500 & $95 \pm 3$ \\
\hline
\end{tabular}

IS+: with immunosuppression;

IS - : without immunosuppression

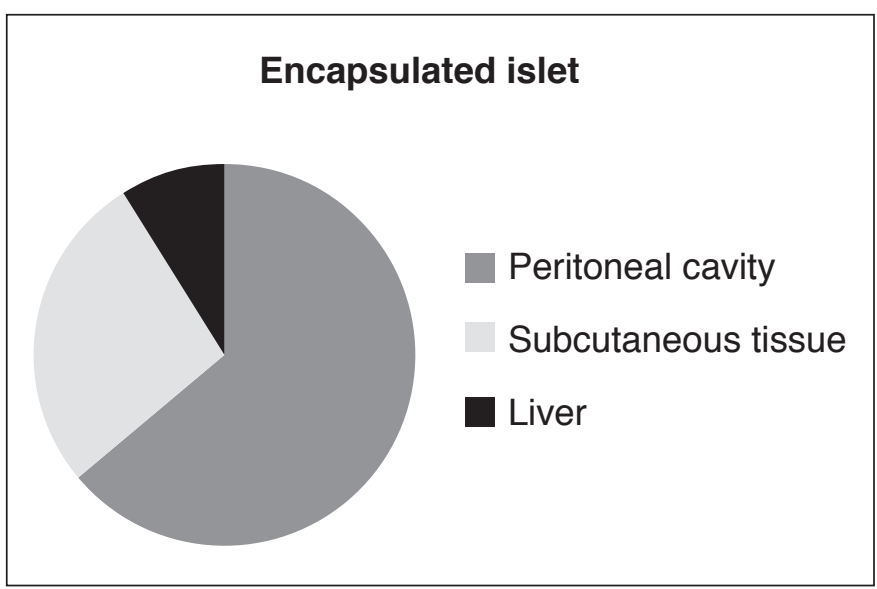

FIGURE 1. Most common sites of implantation of encapsulated islets
The most widely used implantation sites of encapsulated islets (Figure 1).

In contrast, the best islet survival rate in the nonencapsulated islets was achieved by injecting islets into the liver, with an average of 1475 islets implanted per capsule, lasting an average of 164 days with the use of immunosuppression (Table 2).

TABLE 2. Sites of implantation of nonencapsulated islets and islets survival rate (days)

\begin{tabular}{|c|c|c|}
\hline \multicolumn{3}{|c|}{ Nonencapsulated } \\
\hline Author & No. of islets & Results days \\
\hline \multicolumn{3}{|c|}{ Liver } \\
\hline Ikebukuro et al. ${ }^{(19)}$ & 600 & $>365$ \\
\hline Spadella et al. ${ }^{(50)}$ & 1500 & 365 \\
\hline Schneider et al. ${ }^{(44)}$ & 1500 & $97 \pm 2$ \\
\hline Omer et al. ${ }^{(35)}$ & 4000 & 70 \\
\hline Taira M. et al. ${ }^{(52)}$ & 600 & 30 \\
\hline Ikebukuro et al. ${ }^{(18)}$ & 600 & 250 \\
\hline Hara et al. ${ }^{(16)}$ & 500 to 1500 & $\begin{array}{l}\text { IS }+: 10.5 \pm 8.44 \\
\text { IS-: } 12.0 \pm 2.65\end{array}$ \\
\hline Lee. et al. ${ }^{(29)}$ & 1500 & 126 \\
\hline \multicolumn{3}{|c|}{ Kidney } \\
\hline Olsson et al. ${ }^{(34)}$ & 250 & 28 \\
\hline Sawada et al. ${ }^{(42)}$ & 2000 & $>100$ \\
\hline Lan et al. ${ }^{(27)}$ & - & $>60$ \\
\hline Hamamoto et al. ${ }^{(14)}$ & 2500 & 41 \\
\hline Kover et al. ${ }^{(24)}$ & 1500 & $80-120$ \\
\hline Hiramatsu et al. ${ }^{(17)}$ & 200 or 20 & 56 \\
\hline Socha-Urbanek et al. ${ }^{(47)}$ & $1500 \pm 200$ & 150 \\
\hline Laumonier et al. ${ }^{(28)}$ & 3000 to 3200 & $19.5 \pm 5.8$ \\
\hline Omer et al. ${ }^{(35)}$ & 4000 & 70 \\
\hline Sharma et al..$^{(46)}$ & 30 & $30-40$ \\
\hline Hara et al. ${ }^{(16)}$ & 500 to 1500 & $11.0 \pm 2.63$ \\
\hline Han et al. ${ }^{(15)}$ & - & 60 \\
\hline
\end{tabular}

IS+: with immunosuppression;

IS-: without immunosuppression

Other sites of implantation were: subcutaneous tissue $(\mathrm{n}=2500$ islets; 58 days of viability), peritoneal cavity $(\mathrm{n}=$ 10000 islets; 37 days of viability) and bone marrow $(n=1250$ islets; 21 days of viability).

\section{DISCUSSION}

The concept of islet transplantation is not new. Investigators as early as the English surgeon Charles Pybus (1882-1975) attempted to transplant pancreatic tissue to cure diabetes. Most, however, credit the recent era of islet transplantation research to Paul Lacy's studies dating back to more than 3 decades. Lacy's group ${ }^{(25)}$ described a novel method to isolate islets using collagenase, paving the way for future of in vitro and in vivo islet experiments. According to Hara et al. ${ }^{(16)}$, Ballinger and Lacy demonstrated that intraportal islet transplantation corrected experimental 
diabetes in rodents; since then, many transplantation sites have been tested.

Subsequent studies showed that transplanted islets could reverse diabetes in both rodents and non-human primates ${ }^{23}$, ${ }^{43)}$. Lacy ${ }^{(26)}$ observed the feasibility of islet cell transplantation as a therapeutic approach in the probable prevention of the diabetes complications in individuals. Improvements in isolation techniques and immunosuppressive regimens conducted in the first human clinical trials of islet transplantation in the mid of 1980 . Tzakiset et al. ${ }^{(57)}$ described the first successful trial of human islet allotransplantation resulting in longterm reversal of diabetes. Despite continued procedural improvements, only about $10 \%$ of islet recipients in the late of 1990 achieved euglycemia. Shapiro et al. ${ }^{(45)}$ described seven consecutive patients who achieved euglycemia after islet transplantation using a steroid-free protocol and large numbers of donor islets.

In the last 10 years numerous studies were made on islet transplantation in the rodent. We reviewed 56 of these studies; 19 articles (34\%) concerned encapsulated islet and $37(66 \%)$ non-encapsulated islet.

Nonencapsulated islets may be injected into the liver $(4,16,18,19,35,44,50,52)$, kidney $(5,14,15,16,17,24,27,28,32,34,35,42,46,47)$, peritoneal cavity ${ }^{(11,35)}$, bone marrow ${ }^{(41)}$ and subcutaneous tissue $^{(22,48)}$. Ikebukuro et al. ${ }^{(19)}$ showed that islets and bone marrow cells, when injected into the liver using irradiation as immunosuppression, can increase the functionality of the cells for more than 365 days. In addition, Kawakami et al. ${ }^{(22)}$ discovered that basic fibroblast growth factor could increase vascularization and thus achieve islets viability for 112 days, when islets were injected in the subcutaneous tissue.

Many factors can influence the islet viability and it is important to review them. While significant progress has been made in the islet transplantation field, many obstacles remain that currently preclude its widespread application. Three of the most important limitations are low tension of $\mathrm{O}_{2}$ where the islets are implanted, the limited supply of islets for transplantation and also the currently inadequate means for preventing islet rejection.

Encapsulated islets have been used in two ways: microencapsulated islets and macro-encapsulated islets. Macroencapsulated islets have the advantage of being retrievable so that the functions of islets inside can be evaluated at anytime. In contrast, micro-encapsulated islets are one or a few islets enclosed in semi-permeable membranes, which can provide a surface for diffusion, therefore maintaining the functions of islets inside. However, they are irretrievable after transplantation ${ }^{(38)}$.

When islets are transplanted, $50 \%$ of the tissue may be lost in the first few days; this is thought to be due to hypoxic death before vascularization develops ${ }^{(36)}$. Revascularization begins in 7-10 days after transplant, when there's already ischemic damage ${ }^{(21,33)}$. This delayed and insufficient revascularization deprives these islets of oxygen, resulting in cell death and graft failure ${ }^{(12)}$.

The great advantage of the liver as the site of islet transplantation is dual blood supply, which allows the total occlusion of the portal venules, caused by embolization and the non-infarted site of transplantation, which is nourished by blood ${ }^{(4)}$.

In the renal subcapsular space, islets are easily retrieved for histological study. However, vascularization is poor and leads to a low tension of oxygen.

When the islets are implanted into the rodent's peritoneal cavity there is plenty of blood supply to use of, which facilitates the wait for a new revascularization, but it is randomly chosen.

Trying to increase the blood supply of the graft soon after implantation, Cheng et al. ${ }^{(5)}$ have injected vascular endothelial cells $\mathrm{L}$ and vascular endothelial growth factor (VEGF) to stimulate angiogenesis. The use of growth factors was made of in other works too ${ }^{(5,33,62)}$. They saw that in chronically isquemic tissues these factors where decreased and that premature islet revascularization could improve the outcome of islet transplantation and enhance the graft survival. Yu et al. ${ }^{(62)}$ combined SDF-1alfa and VEGF achieving not only new vessels but mature and stable ones.

In a different way, joining bone marrow - derived mesenchymal stem cells function as VEGF secretor to pancreatic islets, Figliuzzi et al. ${ }^{(12)}$ also promoted vascularization. Johansson et al. ${ }^{(21)}$ questioned the early capability of forming new blood vessels, lost days later. They saw that the islets attract blood vessels but fail to grow and connect to recipient blood vessels. He then inhibited the angiostatic factors and restored that capability without any growth factors.

All of these different approaches towards a better vascularization are new and of these, need yet to be sorted the best one.

The difficulty in isolating an adequate number of islets lies on the fact that multiple donors are needed to get patients off exogenous insulin after islet transplantation. Therefore, it is crucial to prepare large numbers of viable and functional islets from a single donor pancreas for clinical transplantation.

It has been proven that the volume of the capsules influences, since the larger the capsule more chances are there of central necrosis ${ }^{(36)}$. Besides necrosis, a major concern is that the low tension of $\mathrm{O}_{2}$ can lead the release of proinflammatory factors. These pro-inflammatory factors elicit a host immune response even in the encapsulated islets. An alternative to prevent these factors is the use of capsules. These can reduce immunogenicity by preventing cellular immune reactions while simultaneously transfers nutrients, oxygen and therapeutic factors. This permits the imitation of moment-to-moment fine regulation of the missing therapeutic factors, avoids a lifetime of immunosuppressive therapy and allows the use of non-human cells, thus overcoming the limited supply of human donor cells ${ }^{(65)}$.

Zhao et al. ${ }^{\left({ }^{64)}\right.}$ have demonstrated that encapsulated islets cultured in $3 \mathrm{D}$ peptide nanofiber provides a superior simulated microenvironment for improving the viability and the secretion function of the islets.

Graft failure of encapsulated islets is usually interpreted as a consequence of a nonspecific body reaction against the capsules that results in fibrotic overgrowth of the capsules, 
with ischemia and subsequent necrosis of the islets ${ }^{(9)}$. Pericapsular overgrowth should not impose a problem as long as the majority of the islet-containing microcapsules is not affected by overgrowth, and remains efficient ${ }^{(6)}$. However, macrophage-derived factors from the overgrown part of the graft may affect the non-overgrown part.

An alternative to these are capsules with new components. Zimmermann et al. ${ }^{(65)}$ have demonstrated that alginate based matrix with $\mathrm{BaCl}_{2}$ crystals enhances the immunoprotecting encapsulation and therefore stabilizes the membrane when in contact with the external $\mathrm{Ba}^{2+}$. Yun et al. ${ }^{(63)}$ have reported that PEG-based chemical immunomodulation can provide a semi-permanent effective therapy that protects transplanted islets at least for 1 year when accompanied by cyclosporine. Furthermore, Vériter et al. ${ }^{(58)}$ have tested originals alginates with respect to sterile lyophilized high mannuronated and they have had an optimum result with high mannuronated with high viscosity alginate.

Another option is the use of TheraCyte ${ }^{\mathrm{TM}}$ which is suited for the maintenance of islets in vivo by allowing cells to be loaded into the chamber at controlled densities and spatial configurations and the promotion of vascularization by the outer membrane of the device ${ }^{(51)}$. In addition, Teramura et al. ${ }^{(54)}$ have proposed as up-to-the-minute method for islet microencapsulation with amphiphilic poly (ethylene glyocol)conjugated phospholipid derivative (PEG-lipid) and DNA hybridization. This enables an individually islet encapsulation and no central necrosis have been observed.

Qi et al. ${ }^{(38)}$ have suggested the use of polyvinyl alcohol macro-encapsulated islets for long-term preservation (7 days) is better, because they allow overcoming the obstacles of insufficient donors and the side effects of immunosuppressive drugs.

In the past decades, allograft survival improved because the development of new and more specific immunosuppressive agents.

Recently it was stated that porcine islet xenotransplantation is possible using cyclosporine $\mathrm{A}(\mathrm{CsA})$ as an immunosuppressive agent. They isolated islets from adult pigs, cultured for 1.5-3 weeks and transplanted in rodents using CsA. The treatment with CsA achieved graft survival to over 134 days $^{(40)}$.

A further immunosuppressive agent used is AEB-071 (AEB). AEB-071 is a specific inhibitor of protein kinase $\mathrm{C}$, which prevents T-lymphocyte activation. Merani et al. ${ }^{(32)}$ investigated the effect of AEB on rat islet allotransplantation alone or in combination with CTLA4-Ig, mycophenolate mofetil or CsA in rodent allogeneic islets transplant model. They demonstrated that AEB is an appropriate immunosuppressive agent for islet transplantation, because it can prolong islet graft survival alone or with CsA, without toxicity on glucose metabolism.

In another study, researchers combined CsA with FTY720 in islet xenotransplantation. They found that this combination inhibited almost all morphological signs of pig-to-rat islet xenograft rejection for up to 24 days after transplantation ${ }^{(30)}$.

Fotiadis et al. ${ }^{(13)}$ used mycophenolatemofetil (MMF) and CsA to check the positive or adverse effects of MMF as a single agent. They proved that the administration of MMF as immunosuppression agent was safe in an experimental model of islet allotransplantation and was equally effective with cyclosporine, with less toxicity.

Balamurugan et al. ${ }^{(2)}$ described the effect of CsA, FK506 or prednisolone monotherapy on preventing monkey islet graft rejection after xenotransplantation in a rodent model. Histological examination indicated that monkey islets survived in the presence of continuous high-dose of immunosuppressive monotherapy in rodents.

Most immunosuppressive drugs, that support successful allograft survival act by inhibiting or depleting T lymphocytes. Tautomycetin (TMC) is a specific inhibitor of protein phosphatase 1, which has a role in cell-cycle control and T-cell activation and promotes T-cell-specific apoptosis. Wee et al ${ }^{(60)}$ investigated the effect of TMC alone and in combination with CsA on rodent islet transplantation. They suggested that CsA and TMC act synergistically to reduce the function of T-effector cells and enhance regulatory cell function in a rodent islet allotransplantation model.

Tacrolimus (FK506) is a different immunosuppressive agent used in the islet transplantation. Balibreadel et al..$^{(3)}$ evaluated in vitro islet low-dose tacrolimus response after pro-inflammatory stimulation. They found that in vitro cytoprotective effect of low-dose tacrolimus on isolated rodent islets decreases both oxidative stress and apoptosis markers after stimulation of pro-inflammatory mediators.

Activation of both the coagulation and the complement cascades is one of the serious obstacles to successful island engraftment. Tokodai et al. ${ }^{(56)}$ suggested that C5a-inhibitory peptide combined with gabexatemesilate may be a useful approach to control the instant blood-mediated inflammatory reaction induced in clinical islet transplantation and one that is free of side effects.

It was demonstrated that graft survival of allograft islets transfected with indoleamine 2, 3-dioxygenase (IDO) transplanted without any immunosuppression was superior to the control group. It is known that IDO exerts immunoregulatory functions suppressing T-cell responses. These data demonstrated that IDO expression induced in islets by lipofection improved metabolic control of streptozotocindiabetic rodents and prolonged allograft survival ${ }^{(10)}$.

The cytoprotection of chitosan hydrogels in xenogeneic islet transplantation was demonstrated by Yang et al. ${ }^{(61)}$. It has showed that islets encapsulated in chitosan hydrogels secreted insulin in response to the glucose stimulation as naked islets with higher cell survival. This study indicates that the chitosan hydrogels deliver and protect encapsulated islets successfully in xenotransplantation.

Finally, a better insight into the causes of microencapsulated islet graft failure may help in finding a way to improve graft survival. One important observation is that microencapsulated autograft and allograft survival rates are similar, which implies that graft failure is not caused by rejection due to allograft recognition ${ }^{(7)}$. If graft failure cannot be explained by allogratrejection, others factors must be involved. De Vos et al. ${ }^{(8)}$ have showed that there 
is a gradual decrease in islet function, a gradual increase in central necrosis, a continuous increased replication of islet cells, and a nonprogressive overgrowth of a portion of microencapsulated islet graft. Three important aspects of the microencapsulated islet graft technique may be associated with these phenomena. The first is related to the biocompatibility, which explains the occurrence of overgrowth. The second is related to the immunoprotective properties of the microcapsules. Immunoprotection is incomplete because capsules may allow the passage of small pro-inflammatory factors, which lead to cell death and dysfunction. The third factor is related to the great distance between the encapsulated islets and the blood supply. An important consequence of the great diffusion distance is the limited supply of oxygen, which leads to hypoxia, causes islet dysfunction and necrosis, and may be responsible for the increase in islet replication.

\section{CONCLUSION}

While significant progress has been made in the islets transplantation field, many obstacles remain to be overcome. Microencapsulation provides a means to transplant islets without immunosuppressive agents and may enable the performance of xenotransplantation. The use of alternative donor sources, fewer islets per capsule and the appropriate deployment location, such as the peritoneal cavity, may give a future perspective to the application of immunoprotective capsules and viability in clinical practice. A variety of strategies, such as genetic engineering, co-encapsulation, improvement in oxygen supply or the establishment of hypoxia resistance will also improve the islet transplantation performance. It remains to be determined which combination of strategies with encapsulation can fulfill the promise of establishing a simple and safe transplantation as a cure for diabetes.

Souza YEDM, Chaib E, Lacerda PG, Crescenzi A, Bernal-Filho A, D’Albuquerque LAC. Transplante de ilhotas de Langerhans em modelos experimentais em roedores. Ilhotas encapsuladas realmente funcionam? Arq Gastroenterol. 2011;48(2):146-52.

RESUMO - Contexto - Diabetes mellitus tipo I afeta cerca de 240 milhões de pessoas no mundo e 7,8\% só nos EUA. Foi estimado que o custo de suas complicações fosse de 5\%-10\% dos custos mundiais em saúde. De acordo com a OMS (Organização Mundial de Saúde), espera-se que cerca de 300 milhões de pessoas desenvolvam o diabetes mellitus até o ano de 2025. É esperado que o transplante de ilhotas pancreáticas seja menos invasivo que o transplante pancreático, opção atual de maior uso. Objetivos - Comparar as ilhotas encapsuladas e as ilhotas livres em roedores nos seguintes aspectos: local de implantação das ilhotas, número de ilhotas, viabilidade e imunossupressão. Métodos - A pesquisa bibliográfica foi conduzida com o uso de citações do MEDLINE/PUBMED e SCIELO que apresentassem termos sobre transplante de ilhotas em roedores no período de 2000 a 2010. Foram achados 2.636 artigos, mas somente 56 desse período foram selecionados. Resultados - Nos 56 artigos utilizados, 34\% eram encapsulados e $66 \%$ eram não-encapsulados. Analisando ambos os tipos de transplante de ilhotas, a maioria delas encapsuladas, foi implantada na cavidade peritonial e as não-encapsuladas, através da veia porta, no fígado. A grande vantagem da cavidade peritonial como local de transplante era a oferta sanguínea. As células endoteliais e o fator de crescimento endotelial foram usados para estimular a angiogênese nas ilhotas, aumentando a vascularização rapidamente após a implantação. Foi também provada a influência das cápsulas, dado que quanto maior a cápsula maior era a chance de necrose central. Em alguns artigos, o uso de imunossupressão demonstrou aumento da expectativa de vida do enxerto. Conclusão - Enquanto algum progresso significativo não tenha sido obtido no campo de transplante de ilhotas, restam ainda muitos obstáculos a serem vencidos. A microencapsulação viabiliza o transplante de ilhotas sem o uso de imunossupressores, o que pode permitir o xenotransplante. O uso de fontes doadoras alternativas, menor quantidade de ilhotas por cápsula e local de implantação adequado, como a cavidade peritonial, podem dar melhor perspectiva na aplicação de cápsulas imunoprotegidas, aumentando viabilidade na prática clínica. Uma série de estratégias, como engenharia genética, coencapsulamento, melhora da oferta de oxigênio ou o estabelecimento de resistência à hipóxia também podem aprimorar os resultados do transplante de ilhotas. Devese determinar ainda qual a combinação de estratégias com relação ao uso de ilhotas encapsuladas que possam cumprir com as promessas de um transplante simples e seguro para a cura do diabetes.

DESCRITORES - Diabetes mellitus tipo I. Transplante das ilhotas pancreáticas. Roedores.

\section{REFERENCES}

1. Bahia L. Os custos do diabetes mellitus [Internet]. São Paulo: Sociedade Brasileira de Diabetes - [cited August 5, 2009]. Available at: http://www.diabetes.org.br/ educacao-continuada/491-os-custos-do-diabetes-mellitus.

2. Balamurugan AN, Nelson EJ, Ramakrishna B, Gunasekaran S. Effect of various immunosuppressive monotherapies on survival and histopathology of monkey islet xenografts in rats. Xenotransplantation. 2007;14:316-22.

3. Balibrea del Castillo JM, Arias-Díaz J, García Martín MC, Vives-Pi M, García Pérez JC, Cantero Cid R, Vara Ameigeiras E, Balibrea Cantero JL. [Cytoprotective effect of low-dose tacrolimus on islets of Langerhans in cultures subjected to stimulation by acute rejection cytokines]. Cir Esp. 2010;87:372-7.

4. Chaib E, Papalois A, Brons IG, Calne RY. [Isogenic islet transplantation on the rat liver (method for isolation and purification of the Langerhans islets)]. Arq Gastroenterol. 2000;37:44-51.

5. Cheng Y, Liu YF, Zhang JL, Li TM, Zhao N. Elevation of vascular endothelial growth factor production and its effect on revascularization and function of graft islets in diabetic rats. World J Gastroenterol. 2007;13:2862-6.

6. de Groot M, Schuurs TA, Leuvenink HG, van Schilfgaarde R. Macrophage overgrowth affects neighboring nonovergrown encapsulated islets. J Surg Res. 2003; 115:235-41

7. De Vos P, De Haan BJ, Wolters GH, Strubbe JH, Van Schilfgaarde R. Improved biocompatibility but limited graft survival after purification of alginate for microencapsulation of pancreatic islets. Diabetologia. 1997;40:262-70.

8. De Vos P, Van Straaten JF, Nieuwenhuizen AG, de Groot M, Ploeg RJ, De Haan BJ, Van Schilfgaarde R. Why do microencapsulated islet grafts fail in the absence of fibrotic overgrowth? Diabetes. 1999;48:1381-8.

9. de Vos P, de Haan BJ, de Haan A, van Zanten J, Faas MM. Factors influencing functional survival of microencapsulated islet grafts. Cell Transplant. 2004;13:515-24.

10. Dellê H, Noronha IL. Induction of indoleamine 2, 3-dioxygenase by gene delivery in allogeneic islets prolongs allograft survival. Am J Transplant. 2010;10:1918-24

11. Figliuzzi M, Cornolti R, Plati T, Rajan N, Adobati F, Remuzzi G, Remuzzi A. 
Subcutaneous xenotransplantation of bovine pancreatic islets. Biomaterials. 2005;26:5640-7.

12. Figliuzzi M, Cornolti R, Perico N, Rota C, Morigi M, Remuzzi G, Remuzzi A Benigni A. Bone marrow-derived mesenchymal stem cells improve islet graft function in diabetic rats. Transplant Proc. 2009;41:1797-800.

13. Fotiadis C, Xekouki P, Papalois AE, Antonakis PT, Sfiniadakis I, Flogeras D, Karampela E, Zografos G. Effects of mycophenolate mofetil vs cyclosporine administration on graft survival and function after islet allotransplantation in diabetic rats. World J Gastroenterol. 2005;11:2733-8.

14. Hamamoto Y, Tsuura Y, Fujimoto S, Nagata M, Takeda T, Mukai E, Fujita J, Yamada Y, Seino Y. Recovery of function and mass of endogenous beta-cells in streptozotocin-induced diabetic rats treated with islet transplantation. Biochem Biophys Res Commun. 2001;287:104-9.

15. Han X, Qiu L, Zhang Y, Kong Q, Wang H, Wang H, Li H, Duan C, Wang Y, Song Y, Wang C. Transplantation of sertoli-islet cell aggregates formed by microgravity: prolonged survival in diabetic rats. Exp Biol Med (Maywood). 2009;234:595-603

16. Hara Y, Fujino M, Nakada K, Kimura K, Adachi K, Li XK. Influence of the numbers of islets on the models of rat syngeneic-islet and allogeneic-islet transplantations. Transplant Proc. 2006;38:2726-8.

17. Hiramatsu S, Grill V. Influence of a high-fat diet during chronic hyperglycemia on beta-cell function in pancreatic islet transplants to streptozotocin-diabetic rats. Eur J Endocrinol. 2001;144:521-7.

18. Ikebukuro K, Adachi Y, Yamada Y, Fujimoto S, Seino Y, Oyaizu H, Hiok $\mathrm{K}$, Ikehara S. Treatment of streptozotocin-induced diabetes mellitus by transplantation of islet cells plus bone marrow cells via portal vein in rats. Transplantation. 2002;73:512-8

19. Ikebukuro K, Adachi Y, Suzuki Y, Iwasaki M, Nakano K, Koike Y, Mukaide H Yamada Y, Fujimoto S, Seino Y, Oyaizu H, Shigematsu A, Kiriyama N, Hamada Y, Kamiyama Y, Ikehara S. Synergistic effects of injection of bone marrow cells into both portal vein and bone marrow on tolerance induction in transplantation of allogeneic pancreatic islets. Bone Marrow Transplant. 2006;38:657-64.

20. International Diabetes Federation (IDF) [Internet]. Why you should care Brussels, Belgium: IDF; 2010 - [cited August 5, 2009]. Available at: http://www. idf.org/why-you-should-care.

21. Johansson A, Olerud J, Johansson M, Carlsson PO. Angiostatic factors normally restrict islet endothelial cell proliferation and migration: implications for islet transplantation. Transpl Int. 2009;22:1182-8.

22. Kawakami Y, Iwata H, Gu YJ, Miyamoto M, Murakami Y, Balamurugan AN, Imamura M, Inoue K. Successful subcutaneous pancreatic islet transplantation using an angiogenic growth factor-releasing device. Pancreas. 2001;23:375-81.

23. Kemp CB, Knight MJ, Scharp DW, Lacy PE, Ballinger WF. Transplantation of isolated pancreatic islets into the portal vein of diabetic rats. Nature. 1973;244:447.

24. Kover KL, Geng Z, Hess D, Benjamin C, Moore WV. CD40/154 blockade and rejection of islet allografts in the streptozotocin and autoimmune diabetic rat. Pediatr Diabetes. 2001;2:178-83.

25. Lacy P, Kostianovsky M. Method for the isolation of intact islets of Langerhans from the rat pancreas. Diabetes. 1967;16:35-9.

26. Lacy P. Workshop on pancreatic islet cell transplantation in diabetes sponsored by the National Institute of Arthritis, Metabolism, and Digestive Diseases and held at the National Institutes of Health in Bethesda, Maryland, on November 29 and 30, 1977. Diabetes. 1978;27:427-9.

27. Lan P, Zhan W, Wang J, Yan L, Xiao L, Wu X. Immune privilege induced by cotransplantation of islet and allogeneic testicular cells. Chin Med J (Engl). 2001;114:1026-9.

28. Laumonier T, Potiron N, Boeffard F, Chagneau C, Brouard S, Guillot C, Soulillou JP, Anegon I, Le Mauff B. CTLA4Ig adenoviral gene transfer induces longterm islet rat allograft survival, without tolerance, after systemic but not loca intragraft expression. Hum Gene Ther. 2003;14:561-75.

29. Lee DY, Ravazzola M, Park BH, Bashmakov YK, Orci L, Unger RH. Metabolic mechanisms of failure of intraportally transplanted pancreatic beta-cells in rats: role of lipotoxicity and prevention by leptin. Diabetes. 2007;56:2295-301.

30. Maeda A, Goto M, Zhang J, Bennet W, Groth CG, Korsgren O, Wennberg L. Immunosuppression with FTY720 and cyclosporine A inhibits rejection of adult porcine islet xenografts in rats. Transplantation. 2003;75:1409-14.

31. Medbury HJ, Hibbins M, Lehnert AM, Hawthorne WJ, Chapman JR, Mandel TE, O'Connell PJ. The cytokine and histological response in islet xenograft rejection is dependent upon species combination. Transplantation. 1997;64:1307-14.

32. Merani S, Pawlick RL, Edgar RL, Toso C, Emamaullee J, Anderson CC, Shapiro AM. Protein kinase C inhibitor, AEB-071, acts complementarily with cyclosporine to prevent islet rejection in rats. Transplantation. 2009;87:59-65.

33. Moya ML, Garfinkel MR, Liu X, Lucas S, Opara EC, Greisler HP, Brey EM. Fibroblast growth factor-1 (FGF-1) loaded microbeads enhance local capillary neovascularization. J Surg Res. 2010;160:208-12.
34. Olsson R, Jansson L, Andersson A, Carlsson PO. Local blood flow regulation in transplanted rat pancreatic islets: influence of adenosine, angiotensin II, and nitric oxide inhibition. Transplantation. 2000;70:280-7.

35. Omer A, Duvivier-Kali VF, Aschenbach W, Tchipashvili V, Goodyear LJ, Weir GC. Exercise induces hypoglycemia in rats with islet transplantation. Diabetes. 2004;53:360-5.

36. O'Sullivan ES, Johnson AS, Omer A, Hollister-Lock J, Bonner-Weir S, Colton CK, Weir GC. Rat islet cell aggregates are superior to islets for transplantation in microcapsules. Diabetologia. 2010;53:937-45.

37. Posset AM, Baker CF, Tomaszweski JE, Markmann JF, Chot MA, Naji A Induction of donor-specific umrespponsiveness by intrathymic islet transplantation. Science. 1990,249:1293-5.

38. Qi Z, Shen Y, Yanai G, Yang K, Shirouzu Y, Hiura A, Sumi S. The in vivo performance of polyvinyl alcohol macro-encapsulated islets. Biomaterials 2010;31:4026-31.

39. Remuzzi A, Cornolti R, Bianchi R, Figliuzzi M, Porretta-Serapiglia C, Oggioni N, Carozzi V, Crippa L, Avezza F, Fiordaliso F, Salio M, Lauria G, Lombard $\mathrm{R}$, Cavaletti G. Regression of diabetic complications by islet transplantation in the rat. Diabetologia. 2009;52:2653-61.

40. Rijkelijkhuizen JK, Töns A, Terpstra OT, Bouwman E. Transplantation of long-term cultured porcine islets in the rat: prolonged graft survival and recipient growth on reduced immunosuppression. Cell Transplant. 2010;19:387-98.

41. Salazar-Bañuelos A, Wright JR Jr, Sigalet D, Benítez-Bribiesca L. Pancreatic islet transplantation into the bone marrow of the rat. Am J Surg. 2008;195:674-8.

42. Sawada T, Asanuma Y, Furuya T, Shibata S, Yasui O, Sato T, Koyama K Induction of systemic tolerance in islet allograft by liver transplantation. Transplant Proc. 2001;33:2995-9.

43. Scharp DW, Murphy JJ, Newton WT, Ballinger WF, Lacy PE. Transplantation of islets of Langerhans in diabetic rhesus monkeys. Surgery. 1975;77:100-5.

44. Schneider S, von Mach MA, Kraus O, Kann P, Feilen PJ. Intraportal transplantation of allogenic pancreatic islets encapsulated in barium alginate beads in diabetic rats. Artif Organs. 2003;27:1053-6.

45. Shapiro AM, Lakey JR, Ryan EA, Korbutt GS, Toth E, Warnock GL, Kneteman NM, Rajotte RV. Islet transplantation in seven patients with type 1 diabetes mellitus using a glucocorticoid-free immunosuppressive regimen. N Engl J Med. 2000;343:230-8

46. Sharma A, Sörenby A, Wernerson A, Efendic S, Kumagai-Braesch M, Tibell A Exendin-4 treatment improves metabolic control after rat islet transplantation to athymic mice with streptozotocin-induced diabetes. Diabetologia. 2006;49:1247-53.

47. Socha-Urbanek K, Socha M, Kwásny M, Fiedor P. Survival of islet allografts under kidney capsule in the recipient preconditioned with or without myeloablation and treated with UVB-irradiated donor bone marrow infusion. Transplant Proc. 2002;34:657-8.

48. Sörenby AK, Wu GS, Zhu S, Wernerson AM, Sumitran-Holgersson S, Tibell AB. Macroencapsulation protects against sensitization after allogeneic isle transplantation in rats. Transplantation. 2006;82:393-7.

49. Sörenby AK, Kumagai-Braesch M, Sharma A, Hultenby KR, Wernerson AM, Tibell AB. Preimplantation of an immunoprotective device can lower the curative dose of islets to that of free islet transplantation: studies in a rodent model. Transplantation. 2008;86:364-6.

50. Spadella CT, Machado JL, Caramori CA, Gregório EA. Successful islet transplantation does not prevent the development of neuropathy in alloxaninduced diabetic rats. Transplant Proc. 2002;34:1296-300.

51. Sweet IR, Yanay O, Waldron L, Gilbert M, Fuller JM, Tupling T, Lernmark A Osborne WR. Treatment of diabetic rats with encapsulated islets. J Cell Mol Med. 2008;12:2644-50.

52. Taira M, Inaba M, Takada K, Baba S, Fukui J, Ueda Y, Kwon AH, Hisha H, Kamiyama Y, Ikehara S. Treatment of streptozotocin-induced diabetes mellitus in rats by transplantation of islet cells from two major histocompatibility complex disparate rats in combination with intra bone marrow injection of allogeneic bone marrow cells. Transplantation. 2005;79:680-7.

53. Tatarkiewicz K, Garcia M, Omer A, Van Schilfgaarde R, Weir GC, De Vos P. $\mathrm{C}$-peptide responses after meal challenge in mice transplanted with microencapsulated rat islets. Diabetologia. 2001;44:646-53.

54. Teramura Y, Minh LN, Kawamoto T, Iwata H. Microencapsulation of islets with living cells using polyDNA-PEG-lipid conjugate. Bioconjug Chem. 2010;21:792-6

55. Tierney LM, McPhee SJ, Papadakis MA. Current medical Diagnosis \& Treatment. International edition. New York: Lange Medical Books/McGrawHill. 2002. p.1203-15.

56. Tokodai K, Goto M, Inagaki A, Nakanishi W, Okada N, Okada H, Satomi S C5a-inhibitory peptide combined with gabexate mesilate prevents the instant blood-mediated inflammatory reaction in a rat model of islet transplantation. Transplant Proc. 2010;42:2102-3. 
57. Tzakis AG, Ricordi C, Alejandro R, Zeng Y, Fung JJ, Todo S, Demetris AJ, Mintz DH, Starzl TE. Pancreatic islet transplantation after upper abdominal exenteration and liver replacement. Lancet. 1990;336:402-5.

58. Vériter S, Mergen J, Goebbels RM, Aouassar N, Grégoire C, Jordan B, Levêque P, Gallez B, Gianello P, Dufrane D. In vivo selection of biocompatible alginates for islet encapsulation and subcutaneous transplantation. Tissue Eng Part A. 2010;16:1503-13.

59. Weber CJ, Safley S, Hagler M, Kapp J. Evaluation of graft-host response for various tissue sources and animal models. Ann N Y Acad Sci. 1999;875:233-54.

60. Wee YM, Choi MY, Kang CH, Kim YH, Kim JH, Lee SK, Yu SY, Kim SC, Han DJ The synergistic effect of Tautomycetin on Cyclosporine A-mediated immunosuppression in a rodent islet allograft model. Mol Med. 2010;16:298-306.

61. Yang KC, Qi Z, Wu CC, Shirouza Y, Lin FH, Yanai G, Sumi S. The cytoprotection of chitosan based hydrogels in xenogeneic islet transplantation: an in vivo study in streptozotocin-induced diabetic mouse. Biochem Biophys Res Commun. 2010;393:818-23.

62. Yu JX, Huang XF, Lv WM, Ye CS, Peng XZ, Zhang H, Xiao LB, Wang SM
Combination of stromal-derived factor-1alpha and vascular endothelial growth factor gene-modified endothelial progenitor cells is more effective for ischemic neovascularization. J Vasc Surg. 2009;50:608-16.

63. Yun Lee D, Hee Nam J, Byun Y. Functional and histological evaluation of transplanted pancreatic islets immunoprotected by PEGylation and cyclosporine for 1 year. Biomaterials. 2007;28:1957-66.

64. Zhao M, Song C, Zhang W, Hou Y, Huang R, Song Y, Xie W, Shi Y, Song C. The three-dimensional nanofiber scaffold culture condition improves viability and function of islets. J Biomed Mater Res A. 2010;94:667-72.

65. Zimmermann H, Zimmermann D, Reuss R, Feilen PJ, Manz B, Katsen A, Weber M, Ihmig FR, Ehrhart F, Gessner P, Behringer M, Steinbach A, Wegner LH, Sukhorukov VL, Vásquez JA, Schneider S, Weber MM, Volke F, Wolf R, Zimmermann U. Towards a medically approved technology for alginate-based microcapsules allowing long-term immunoisolated transplantation. J Mater Sci Mater Med.2005;16:491-501.

Received 26/10/2010 Accepted 19/11/2010 